\title{
Prevailing methods of controlling weevils among kolanut traders of South-West Nigeria
}

\author{
R. T. Olorunmota ${ }^{1}$, E. U. Asogwa ${ }^{1}$, A. V. Oyedokun ${ }^{1}$, B. A.Ogundeji ${ }^{1}$, O. A. Orimogunje ${ }^{1}$, E.E.O \\ Agbebaku $^{1}$ and K. O. Oyeledun ${ }^{1}$
}

${ }^{1}$ Cocoa Research Institute of Nigeria, P.M.B. 5244, Ibadan, Nigeria

*Corresponding Author: olorunmotatemilade@gmail.com

DOI: $10.31364 /$ SCIRJ/v9.i06.2021.P0621862

http://dx.doi.org/10.31364/SCIRJ/v9.i06.2021.P0621862

\begin{abstract}
Authors' contributions
This work was carried out in collaboration with all authors. Author RTO designed the study, managed the literature searches and wrote the first draft of the manuscript. Authors RTO, EUA, AVO, and BAO wrote the protocols, carried out the survey and managed the manuscript. Author RTO, BAO and OAO performed and managed statistical analysis. All authors read and approved the final

manuscript.
\end{abstract}

\begin{abstract}
The problem posed by insect pests of kola nut in storage is a major one. Thus, various control measures are employed by kola nut traders to combat the growing menace. A field survey was conducted to assess the prevailing methods of weevil control among kola nut traders in southwestern Nigeria. Structured questionnaires were used to collect data on personal characteristics of respondents, kola weevil control methods employed and the perceived effectiveness. Data obtained were analyzed using descriptive statistics. Results showed that $95 \%$ of traders were female, $56.67 \%$ were above 50 years with the mean age at 53.25. Most of the respondents $(82.5 \%)$ lack formal education while the remaining $(17.5 \%)$ had primary school education. Of the respondents $80 \%$ were married with most $(62.5 \%)$ trading exclusively with kola nut while others (37.5\%) also added bitter kola. Most of the respondents $(95 \%)$ identified Balanogastris kolae as the weevil attacking kola nuts storage while others identified Sophorhinus species also. Majority of the respondents (83\%) adopted the use of Aluminium phosphide (purchased from hawkers in the market) in controlling weevils during kola storage. Some store kola nuts for as long as a year before selling it, thus re-application of chemical is done to keep the nuts weevil-free. Re-infestation after treatment is low and majority disposed weevil-infested kola nuts at a cheaper rate, causing economic loss. Though traders use recommended chemicals, there is the need to provide safer alternatives due to high level of illiteracy among kola traders which could cause wrong use of the chemicals. Government agencies should check sources of chemical supplies to kola nut traders and train them on proper usage.
\end{abstract}

Key words: Kolanut, weevil, Balanogastris Sophorhinus, traders

\section{INTRODUCTION}

The cola species are genus of tree native to the tropical rainforests of Africa, classified in the family Sterculiaceae and order Malvaceae. The Cola family has about twenty-five species, most of which are non-edible (Lowor et al., 2010) The mostly used cola species are C. verticillata(Thonn.); C. acuminata Schott and Endl.; and C. nitida(Vent.), with the later two not only edible but have significant economic importance in the forest area of West Africa, Caribbean Island, Mauritius, Sri Lanka and Malaysia (Ndagi et al., 2012). Kolanut refers to the cotyledons of some species of cola. C. nitida has two cotyledons and the seed splits into two halves while C. acuminata has more than two and sometimes up to six cotyledons, which splits into corresponding number of cotyledons. Colour variations may occur among nuts extracted from the same pod like red, pink or white. Amongst other parameters such as size, flavour and storage quality, colour of the nuts determine to a large extent, the quality and market price of the nuts.

www.sciri.org

(C) 2021, Scientific Research Journal

http://dx.doi.org/10.31364/SCIRJ/v9.i06.2021.P0521862

This publication is licensed under Creative Commons Attribution CC BY. 
Cola nitida was originally distributed along the West Coast of Africa, including Sierra Leone and the Republic of Benin, with highest frequency and variability found in the forest areas of Côte d'Ivoire and Ghana (Opeke, 1992) Cultivation of $C$. nitida was carried eastwards through Nigeria towards Cameroon and the Congo around 1900, and spread westwards as far as Senegal (Opeke, 1992). C. nitida is planted through Senegal, Guinea, Liberia, Côte d'Ivoire, and Ghana towards the western part of Nigeria (Voelcker, 1935). Southern Nigeria is considered the center of occurrence of $C$. acuminata, with its original area of distribution stretching from Nigeria to Gabon. The kola nut has been in use for a long time, with its characteristic bitter taste rich in caffeine, theobromine and kolanin, which are all stimulants. The nut is chewed in many parts of West African cultures, primarily to restore vitality and to ease pangs of hunger (Asogwa et al., 2012). The role of kola nut in the tradition and spiritual practice of many West African ethnic groups cannot be over emphasized (Atanda et al., 2001).

Nigerian kola nut production accounts for about $70 \%$ of world's kola nut with an annual estimate of 200,000 metric tons of fresh nuts, mostly from South west, Nigeria (CBN, 2002). The south west produces about $88 \%$ of the produce. It was reported that about $10 \%$ of the produce is exported, while the rest is locally consumed (Oluokun and Oladokun, 1999; Okunade, 2003).

The problems posed by insect pests of kola nuts in storage are detrimental to the little production often achieved by kola nut farmers. The most destructive and economically important insect pests of kola nut are the weevils, Balanogastris kolae and Sophrorhinus spp. Weevil attack is from field to store and its infestation promotes secondary invasion by other micro organisms, especially fungi which reduces the market value and eventually results in total destruction of the nuts. It is the most serious post-harvest problem of kola nut that both kola nut farmers and traders face. Significantly high kola nut damage by weevil is recorded in late harvest, however up to 100\% loss of nuts can be recorded in storage, if not controlled (Daramola, 1973; Asogwa et al., 2008).

The use of phostoxin (Aluminium phosphide) fumigants which produces toxic phosphine gas to control weevil was reported being effective, with all the developmental stages of weevils killed in 1 tablet of aluminium phoshide in 100litres air-tight drum containing $3.5 \mathrm{~kg}$ of kolanut. Unfortunately, most kola nuts produced in Nigeria are consumed raw with high level of pesticide residue while treating the stored nuts against weevil infestation. Hence there is a need to continuously survey existing methods of kola nut curing among traders.

The objectives of the study are to;

(i) assess the socio-economic characteristic of the respondents.

(ii) examine the method of insect pest control employed by the respondents.

(iii)determine the efficacy of method employed by the respondents.

\subsection{Hypothesis of the Study}

$\mathrm{Ho}_{1}$ : There is no significant relationship between socio-economic characteristics and methods of insect pest control employed by kola traders.

$\mathrm{Ho}_{2}$ : There is no significant relationship between post-treatment infestation and methods of insect pest control.

\section{MATERIALS AND METHODS}

This study assessed methods of insect control among kola nut traders in three Southwestern States of Nigeria namely, Oyo, Ogun and Osun. Multi-stage sampling procedure was used to select the respondents for the survey. The selected States were chosen because they were known for kola production. Forty kola nut traders were chosen from each State making a total of 120 respondents in the three States. Data were collected from the respondents using structured interview schedule. Data on socio- economic characteristics of the respondents, methods of insect pests control employed by each trader and post-treatment effect were collected. Data was analyzed with the aid of SPSS version 23. The socio-economic characteristic of the farmers and their methods of insect pest control were

www.scirj.org

(C) 2021, Scientific Research Journal

http://dx.doi.org/10.31364/SCIRJ/v9.i06.2021.P0521862

This publication is licensed under Creative Commons Attribution CC BY. 
analyzed using frequency and percentage. Chi-square analysis was used to test the relationships between the socio-economic characteristics of the kola traders and their weevil control methods.

\section{RESULTS AND DISCUSSION}

From this study, findings showed that majority (95\%) of the kola nut traders were women (Table 1). This has to a large extent substantiated the defined role played by women in processing and marketing of agricultural produce as reported by the Federal Ministry of Agriculture \& Rural Development that women handles bulk of processing (Sahel, 2014).

Table 1 show that fewer populations $(17.5 \%)$ of kola nut traders had primary education only while a higher percentage $(82.5 \%)$ had no formal education. This high level of illiteracy among the respondents may lead to low level of adoption and practice of insect pest control with less dependence on synthetic chemicals, this is in consonance with the findings of Sherine and Soha (2012) that farmers with formal education had knowledge about negative effects of pesticides. Table 1 also showed that $80.0 \%$ of the respondents were married, and $20.0 \%$ were widow.

Table 1 reveals that majority $(67.50 \%)$ of the respondents traded with kolanut exclusively, while $32.5 \%$ combined bitter kola with their business. This shows that kola trading served as a major source of livelihood among the traders which agrees with the assertion of Gebissa (2006); Nzekwu,(1961); Egbe and Shobamiwa,(1989).

Table 2 shows that kola traders with trading experience below or equal to ten years were low $(9.2 \%)$, while those with experience of 11-20 and 21- 30 years were comparatively high (23.3\% each) and traders with above 40 years experience were the majority (26.7\%). Those between 31 and 40 were however not relatively low, (17.5\%). Generally these traders can be considered highly experienced.

The number of basket of kola nut traded with varied among traders as shown in Table 2. While only $2.5 \%$ traded with less than one basket, traders with both between 1-5 and 6-10 kolanut baskets recorded 29.2\% each. Also traders with 11-15 baskets were 13.3\% and those trading with above 15 baskets were $25.8 \%$. This high volume of trade is associated with great risk that may justify the need to minimize or avert where possible the danger of weevil infestation in kola nut trading.

Comparatively high percentage $(88.3 \%$ ) of respondents employed the use of insecticide - Phostoxin (Aluminium phosphide), in controlling kola weevil (Table 2). Conversely, relatively low percentage of traders, $2.5 \%$ and $1.7 \%$ employed the use of botanical method and IPM (Integrated Pest Management) respectively. However, 7.5\% of these traders do not treat their kola nut at all, though this seems low but it serves as an encouragement for pesticide-free produce.

Most of the traders were above fifty years of age with young population (Less/equal to 40) relatively low, as only $17.50 \%$ of them were involved while middle age (41-60) traders were below average (47.50\%). Average age (in years) of traders in Oyo state was higher (55.23); than others. Osun had the lowest (51.43), while, Ogun recorded 53.10 years, which is comparatively close to the overall average of 53.25 years (Table 3). It had been reported that people in developed economies achieve the highest productivity on average at around 50 years of age, above which a decline in economy may be experienced (Peterson and Martina 2019). The study of Guancheng et al (2015) in China, on impact of aging labor population on farmland output, also revealed that the average in the area with the highest degree of economic development in the southern region was 54.8 years, while the average in the least developed economies in the north was 55.8 years.

Table 4 shows weevil control methods among Kola nut traders from each State, with higher preference for the use of synthetic chemical recorded in all the States. Both Oyo and Ogun States recorded $87.50 \%$ chemical usage in kola weevil control while Osun recorded $90 \%$. Only 2.5\% respondent in each state employed use of botanical control while $2.5 \%$ traders from both Osun and Ogun use integrated pest management (IPM). It was also revealed that no-treatment of kola nut is practiced by fewer percentage of traders across the three States. While Oyo State recorded comparatively fair percentage (10\%) for no treatment, Osun and Ogun recorded $2.5 \%$ and 5\% respectively. The high use of chemical among these traders is of great concern as the nuts are mostly consumed raw, though the chemical used is recommended. From Table 2, it was found that $100 \%$ of kola nut traders that use chemical in controlling kola weevil purchased it from hawkers in the market which increases the dangers associated with pesticide as expired or fake products may be sold to these traders with low level of education.

www.sciri.org

(C) 2021, Scientific Research Journal

http://dx.doi.org/10.31364/SCIRJ/v9.i06.2021.P0521862

This publication is licensed under Creative Commons Attribution CC BY. 
There was a low record (17.5\%) of re-infestation after pesticides treatment among all respondents from the three States (Table 2). Thus chemical control of the weevil was very effective as reported by different authors except for the associated health risks (Adedire and Ajayi 1996; Murdock and Kitch, 1997; Ofuya et al 2005). Period of weevil re-infestation as shown in Table 2 revealed that12 months period was high $(85.7 \%)$, while re-infestation under 1 month was relatively low. Duration of kola storage before selling varied among traders, only $6.7 \%$ traders stored kola for less than one month in the study area, while $25.8 \%$ stored for between 1-6 months. Majority of the traders (41.7\%) stored for 7-12months. Traders that stored kola between 13-18 months were low (3.3\%) while storage for $19-24$ months and above 24 months were 15 and $7 \%$ respectively.

Table 2 also showed that $73.3 \%$ of kola nut traders sold weevil-infested nuts at a cheaper rate while $26.7 \%$ of them discard weevilinfested nuts. In the two cases losses were incurred though those that were able to sell it at a cheaper rate would incur lesser loss. This may inspire the choice of chemical control to avert total loss as in the case of traders who discard weevil infested nuts. 
Table 1: Personal characteristics of the respondents $(n=120)$

$\underline{\text { Variables }}$ Frequency Percentage Mean

Sex

Male 6 5.0

Female 114 95.0

Age (years)

Less/equal to 40 21 17.5

41-50 31 25.8

51-60 26

61-70

Above 70

Educational Status

Primary

None

99

Marital Status

Married

96

80.0

Widow

Occupation

Kola trading exclusively

$\underline{\text { Kola trading with bitter kola }}$ 45 37.5

Source: Field Survey 2019

Table 2 : Trading experience of kola nut traders

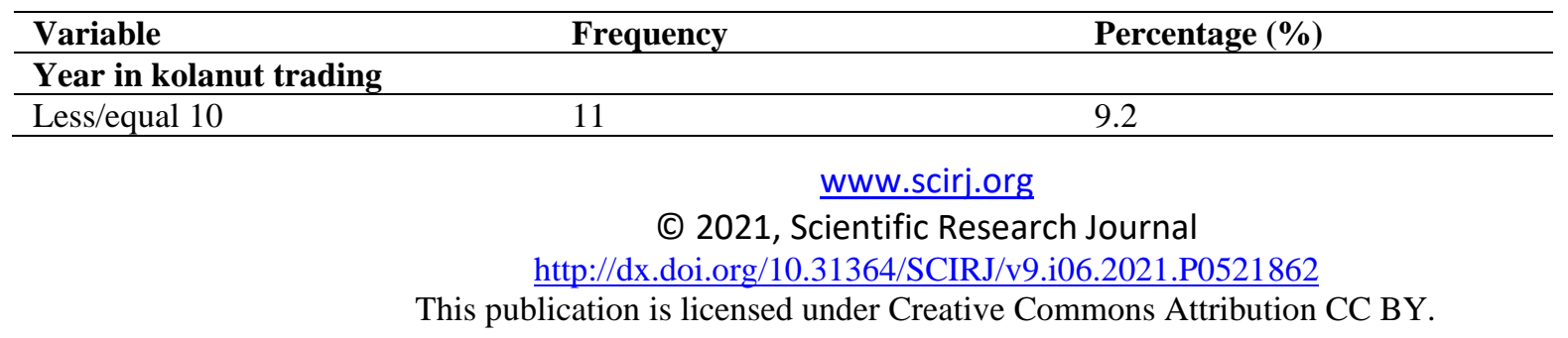




\begin{tabular}{|c|c|c|}
\hline $11-20$ & 28 & 23.3 \\
\hline $21-30$ & 28 & 23.3 \\
\hline $31-40$ & 21 & 17.5 \\
\hline Above 40 & 32 & 26.7 \\
\hline \multicolumn{3}{|c|}{ Number of basket traded with } \\
\hline Under 1 & 3 & 2.5 \\
\hline $1-5$ & 35 & 29.2 \\
\hline $6-10$ & 35 & 29.2 \\
\hline $11-15$ & 16 & 13.3 \\
\hline Above 15 & 31 & 25.8 \\
\hline \multicolumn{3}{|c|}{ Method of weevil control } \\
\hline None & 9 & 7.5 \\
\hline IPM & 2 & 1.7 \\
\hline Botanical & 3 & 2.5 \\
\hline Chemical & 106 & 88.3 \\
\hline \multicolumn{3}{|l|}{ Source of Chemical } \\
\hline Licensed Agencies & - & - \\
\hline Hawkers in the market & 106 & 100 \\
\hline \multicolumn{3}{|c|}{ Post-treatment infestation } \\
\hline Yes & 21 & 17.5 \\
\hline No & 99 & 82.5 \\
\hline \multicolumn{3}{|c|}{ Period of Kolanut storage (month) } \\
\hline Under 1 & 8 & 6.7 \\
\hline $1-6$ & 31 & 25.8 \\
\hline $7-12$ & 50 & 41.7 \\
\hline $13-18$ & 4 & 3.33 \\
\hline $19-24$ & 18 & 15.0 \\
\hline Above 24 & 9 & 7.5 \\
\hline \multicolumn{3}{|c|}{ Period of Re infestation } \\
\hline Under 1 month & 3 & 14.3 \\
\hline $1-2$ months & 18 & 85.7 \\
\hline \multicolumn{3}{|c|}{ Weevil infested nut usage } \\
\hline Sold at cheaper price & 88 & 73.3 \\
\hline Discarded & 32 & 26.3 \\
\hline
\end{tabular}

Source : Field Survey 2019

Table 3: Age distribution among Kolanut traders

\begin{tabular}{lrrrrr} 
Variable/States & Oyo & Osun & Ogun & Overall & $\%$ \\
\hline Age & & & & & \\
\\
$31-40$ & 5 & 8 & 8 & 21 & 17.50 \\
$41-50$ & 11 & 13 & 7 & 31 & 25.83 \\
$51-60$ & 8 & 8 & 10 & 26 & 21.67 \\
$61-70$ & 12 & 8 & 12 & 32 & 26.67 \\
$>70$ & 4 & 3 & 3 & 10 & 8.33 \\
Mean & 55.23 & 51.43 & 53.10 & 53.25 & \\
\hline
\end{tabular}

Source: Field Survey 2019 
Table 5 shows that educational status of the traders was significantly $\left(\chi^{2}=10.361, p=0.016\right)$ related to weevil control method. Thus the low level of education among traders determined the method of weevil control. Improvement on their educational status can guide the choice of kola weevil control method. Age of traders was not significantly $\left(\chi^{2}=17.407, \mathrm{p}=0.135\right)$ related to weevil control thus traders were rigidly used to their long old practice of using chemical, this agrees with Max (2015), who reported that age affected negative significance toward level of technology adoption. Table 5 revealed that re-infestation after treatment and use of weevil-infested nuts were significantly related to control method employed.

Table 4: Weevil control methods among Kolanut traders in each State

$\begin{array}{lllc}\text { State } & \text { Method } & \text { Frequency } & \text { Percentage } \\ \text { Oyo } & \text { None } & 4 & 10.00 \\ & \text { Botanical } & 1 & 2.50 \\ & \text { Chemical } & 35 & 87.50 \\ \text { Osun } & \text { None } & 2 & 5.00\end{array}$




\begin{tabular}{|c|c|c|c|}
\hline & IPM & 1 & 2.50 \\
\hline & Botanical & 1 & 2.50 \\
\hline & Chemical & 36 & 90.00 \\
\hline Ogun & None & 3 & 7.50 \\
\hline & IPM & 1 & 2.50 \\
\hline & Botanical & 1 & 2.50 \\
\hline & Chemical & 35 & 87.50 \\
\hline
\end{tabular}

Source: Field Survey 2019

Table 5: Chi-square analysis of relationship between socio-economic characteristics, Post-treatment infestation and Weevil Control Method among kolanut traders

\begin{tabular}{lccll}
\hline Variables & $\mathbf{X}^{\mathbf{2}}$ & Df & P- value & Remark \\
\hline & & & & \\
Age & 17.407 & 12 & 0.135 & NS \\
Education & 10.361 & 3 & 0.016 & Significant \\
Year of experience & 15.841 & 12 & 0.199 & Not significant \\
Storage period & 1.961 & 3 & 0.982 & Not significant \\
Re-infestation & 64.153 & 3 & 0.000 & Significant \\
Use of weevil-infested nut & 10.947 & & 0.012 & Significant
\end{tabular}

\section{CONCLUSION AND RECOMMENDATION}

The findings of this study showed that women dominated kola nut trading in the study area. The fact that kola traders in the study area are advancing in age, coupled with prominently high level of illiteracy among them may lead to non adoption of safer alternatives of kola weevil control methods such as botanical method. Also high dependence on synthetic insecticide for weevil control can be attributed to its efficacy to minimize economic loss. However, long storage period of kola nut and short period of re-infestation will encourage continual use of chemicals which may lead to accumulation of chemical residue over long storage period.

To minimize economic loss and reduce pesticide residue in kola nut which is usually consumed raw, researchers need to develop potent botanicals to control the kola weevils. The government also needs to sensitize kola nut traders on safer alternatives in controlling storage weevils and check the influx of hazardous pesticides into the market, as traders were seen buying pesticides directly from hawkers in the markets. Re-introduction of marketing board may also deter traders from illicit use of pesticides.

Adding value to kola nut to develop product with similar masticatory effect as the kolanut with prolonged shelf life may reduce the storage of kola nut over long period of time that demands continual use of chemicals.

\section{COMPETING INTERESTS}

Authors have declared that no competing interests exist.

www.sciri.org

(C) 2021, Scientific Research Journal

http://dx.doi.org/10.31364/SCIRJ/v9.i06.2021.P0521862

This publication is licensed under Creative Commons Attribution CC BY. 


\section{REFERENCES}

1. Adedire, C. O. and Ajayi, T.S. 1996. Assessment of the Insecticidal properties of some plant extracts as grain protectants against the maize weevil, Sitophilus zeamais Mostchulsky. Nigeria Journal of Entomology 13:93 -101.

2. Asogwa, E.U., Ojelade, K.T.M., Anikwe, J.C. and Ndubuaku, T.C.N. (2008). Major kola insect pests. In: Insect pests of cocoa, kola, coffee, cashew, tea and their control. Answers Communication Concepts, Apapa, Lagos, Nigeria. Pp 57-60.

3. Asogwa, E.U., A.E. Agbongiarhuoyi, F.C. Mokwunye, I. Ndagi, S. Adebiyi, and T.C.N. Ndubuaku, T.C.N. The challenges of kolanuts processing, trade and export from Nigeria and other sub-saharan African countries,International Journal of Science and Nature 3(1), 2012, 6-11.

4. Central Bank of Nigeria (2002). Memorandum on Agricultural Financing. Presented at the 32nd regular meeting of the National Council on Agricultural and Rural Development held at Yola, Adamawa State, pp 10.

5. Daramola, A. M (1973). The bionomic of the kola weevils, Sophrorhinus spp. (Coleoptera: Curculionidae). Ph.D. thesis. University of Ibadan, Nigeria. 325pp.

6. Egbe, N.E. and Shobamiwa, O. (1989) Utilization of Cocoa, Kola, Coffee, Cashew, Tea In Nigeria: In Progess in Tree Crop Research, $2^{\text {nd }}$ Edition, Cocoa Research Institute of Nigeria, Ibadan.

7. Gebissa, E. (2006) Kola Is God's Gift: Agricultural Production, Export Initiatives and the Kola Industry in Asante and the Gold Coast c 1820-1950 (review) - Africa Studies Review, 49(3):94-96.

8. Guancheng Guo, Qiyu Wen and Jingjuan Zhu (2015)The Impact of Aging Agricultural Labor Population on Farmland Output: From the Perspective of Farmer Preferences. Research Article | Open Access Volume 2015 |Article ID 730618 https://doi.org/10.1155/2015/730618

9. Lowor, S.T.; P.C. Aculey, and M.K. Assuah, Analysis of some quality indicators in cured Cola nitida (Vent)., Agriculture and Biology Journal of North America, 1(6), 2010, 1206- 1214.

10. Max, N.A. Effect of Farmers Socio-economic Toward Adoption Level of Agricultural Technology in Sigi Regency Indonesia. Journal of Applied Sciences, 15(5) 2015 826-830

11. Murdock, L.L. and Kitch, C. 1997. Post-harvest storage of cowpeas in Sub- Saharan Africa. Bulletin of Entomological Research 52,635-645.

12. Ndagi, I.; F.D. Babalola; I.U. Mokwunye; C.F. Anagbogu; I.A. Aderolu; O. Ugioro; E.U. Asogwa; M. Idrisu and F.C. Mokwunye (2012). Potentials and challenges of kolanut production in Niger State, Nigeria. International Scholarly Research Network. Vol. 2012, Article ID 492394. Pp. 1-9.

13. Nzekwu, O.(1961). Kolanut. Nig. Mag.(71): 298-305

14. Oluokun, J.A. and Oladokun, M.A.O.(1999). The effects of graded levels of brewers spent grain and kolanut pod meal in the performance characteristics and carcass quality of rabbits. Nigerian Journal of Animal Production.26 : 71-77.

15. Okunade, S.O. (2003). Methods of pest control in stored kola nuts in Nigeria. Noma Magazine, Published by Institute for Agricultural Research, Samaru, Zaria. Pp. 21-25.

16. Opeke, L.K. Tropical tree crops (Ibadan: Spectrum, 1992).

17. Ofuya, T.I., Olotuah, O. F., and Akinyoade, D. O. 2005. Efficacy of Eugenia aromatic powder prepared at different times in the control of Callosobruchus maculatus Fab (Coleoptera: Bruchidae) infesting stored cowpea seeds.

18. Petersen Thiep and Martina Lizarazo Lopez (2019) Demography and Foreign Trade: What are the effects of Aging Population on the Current Account Balance of an Economy. New Perspective on Global Economic Dynamics https://gedproject.de/trade-and-investment/effects-of-aging-population

19. Sahel, (2014).The role of women in Nigeria Agriculture.

20. Sherine Gaber and Soha Hassan Abdel-Latif (2012) Effect of education and health locus of control on safe use of pesticides. Journal of Occupational Medicine and Toxicology 7,(3) 2012

21. Voelcker, O. J. (1935). Cotyledon colour in kola. Tropical Agriculture12, 231-234.

www.sciri.org

(C) 2021, Scientific Research Journal

http://dx.doi.org/10.31364/SCIRJ/v9.i06.2021.P0521862

This publication is licensed under Creative Commons Attribution CC BY. 
